\title{
予冷ターボジェットェンジンにおけるジェット噴射を用いた熱交換器の除霜*1 Defrosting of a Heat Exchanger for Precooled Turbojet Engines Using Jet Impingement
}

\author{
吹 場 活 佳 ${ }^{* 2 * 3} \cdot$ 井上翔 ${ }^{* 4} \cdot$ 佐 藤 哲 也*5 $\cdot$ 大久保 英 敏 ${ }^{* 4}$ \\ Katsuyoshi Fukiba, Shou Inoue, Tetsuya SAto and Hidetoshi Ohkubo
}

Key Words : Heat Transfer, Engines, Frost Formation, Defrost, Jet Impingement

\begin{abstract}
An innovative defrosting method for precooled turbojet engines are presented, and validated in this study using experimental methods. High speed gas jet was impinged on the cooling tubes of a heat exchanger for the purpose of defrosting. The coolant of the heat exchanger was liquid nitrogen, and whose temperature was $83 \mathrm{~K}$. The air flow speed, the air temperature and the air humidity were $1.0 \mathrm{~m} / \mathrm{s}, 23^{\circ} \mathrm{C}$ and $59 \%$, respectively. The effects of the jet duration, jet intervals and humidity of the jet gas on the heat exchange were assessed. As a result, we found that the presenting defrosting method is valid for the defrosting of the precooler.
\end{abstract}

\section{1. は じめに}

予冷ターボエンジンは通常のジェットエンジンに主流冷 却用の熱交換器であるプリクーラを搭載し, 燃料である液 体水素や LNG を用いて主流を冷却することにより性能を 向上させるエンジンである11. 予冷ターボエンジンはイン テークにおいて空気が減速された際に高温になるような, 超音速/極超音速飛行用の推進機として特に有効であること が知られており，研究が続けられてきた。最近では航空用 エンジン以外の分野でも, 工業用 LNG の冷熱利用方法の 一つとして地上用ガスタービンシステムと予冷装置を組合 せ発電システムの効率化を図っている例もある2). しかし, 主流空気の冷却時にプリクーラの冷却配管に発生する霜が 実用化に際し問題となることが明らかになっている33.

熱交換器における着霜の問題は, 地上空調用の熱交換器 における着霜問題を背景としてこれまでに多くの研究がな されており4), その対処法に関してもいくつものアイデアが 提案されている5). しかしこれらのアイデアは基本的にシ ステムの質量増加を招くものである。 たとえば，地上空調 用の熱交換器によく用いられる除霜方法として, 熱によっ て霜を融解させる方法がある。しかし霜を融解させている 間は冷却ができないため，熱交換器を 2 台用意するなどの 対策が必要となり, 大幅な質量増加を招く.また予冷夕ー ボエンジンの研究において原田ら ${ }^{6)}$, 木村ら7) はアルコー ルの噴霧による除霜方法を提案し一応の成功を収めた。し

\footnotetext{
*1 C) 2008 日本航空宇宙学会

平成 19 年 3 月 1 日, 第 47 回航空原動機・宇宙推進講演会にお いて発表. 平成 20 年 1 月 31 日原稿受理

*2 宇宙航空研究開発機構総合技術研究本部

*3 現 室蘭工業大学航空宇宙機システム研究センター

*4 玉川大学大学院工学研究科機械工学専攻

*5 早稲田大学理工学術院基幹理工学部機械科学・航空学科
}

かしこの方法では，新たに除霜用の液体および噴霧装置な どを搭載する必要があり, 重量増が懸念される。このよう な熱交換器の質量増加は航空用のエンジンにとって致命的 である。

そこで本研究では, 高圧ガスにより高速のジェットを作 り出し, これをプリクーラ冷却配管に衝突させることで除 霜を行う方法を提案する ${ }^{8)}$. 第 1 図に, 提案する除霜システ ムを搭載した予冷ターボジェットエンジンの概念四を示す. 図において，燃料である液体水素や LNG はコンプレッサ 上流のプリクーラを通り主流空気との熱交換を行うが，こ のプリクーラに対しジェットを噴射して除霜を行う。この 方法によれば, 高圧源をコンプレッサ下流からバイパスさ れた空気とすることで, 除霜装置に必要な重量増を配管と バルブおよび噴射器のみにすることが可能である.

本稿では熱交換器の着霜をジェット噴射により除去する手 法について, 基礎研究を行った成果を報告する. 特に今回 は熱交換器を通す冷媒を液体窒素とし, 冷却面温度を $80 \mathrm{~K}$ 付近に設定して実験を行う。この冷却面温度領域における

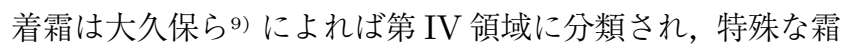
層成長を見せることが知られている。しかしながらこの領 域に対する熱交換器の実験デー夕はほとんど示されていな い.この領域を取り扱った数少ない研究例として原田6,10) のものがあるが，原田によればこの領域の発生する霜層は 密度が低くもろいとされている。これは上記に示したジェッ トの衝突による除霜方法にとって有利な条件であり, 効果 が期待できる. 本研究では小型の熱交換器模型と恒温恒湿 空気供給装置を用いた実験装置により，第 IV 領域の霜層 に対するジェット噴射による除霜の有効性を検討する.

\section{2. 実 験 方 法}

第 2 図に，本実験で使用した実験装置の概略図を示す。実 


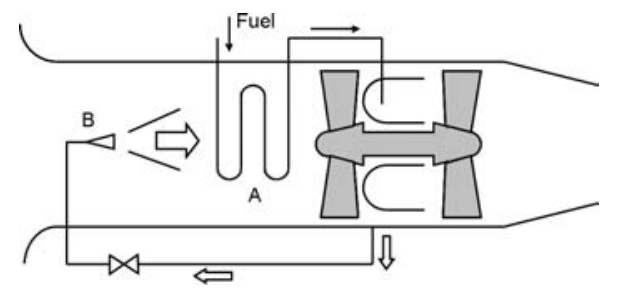

$\mathrm{A}$ ：プリクーラ $\quad \mathrm{B}$ ：ジェット噴射ノズル

第 1 図ジェット噴射を用いた除霜装置を搭載した予冷ターボジェッ トエンジン

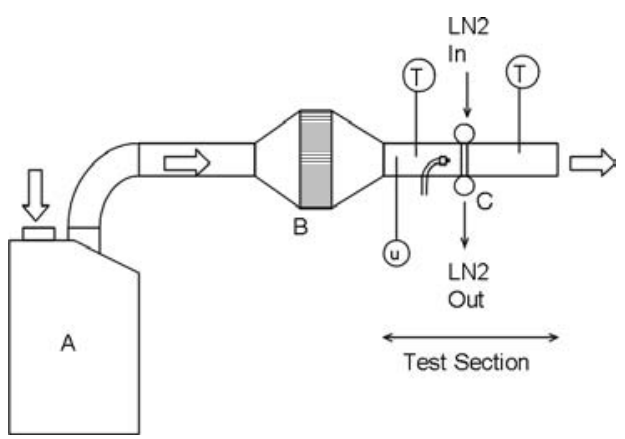

(a) 試験装置全体図
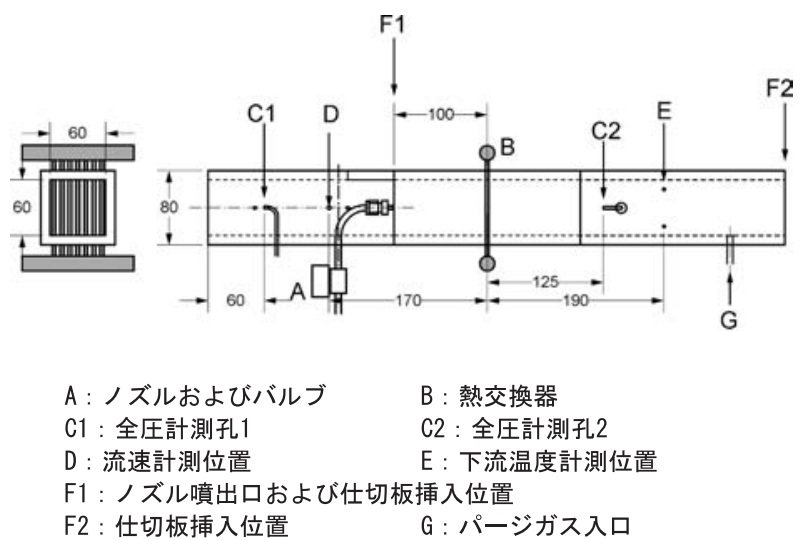

(b) テストセクション機器配置図

第 2 図 実験装置

験装置は恒温恒湿空気供給装置（A），ダクトおよび整流塔 (B)，ジェット噴射装置および熱交換器の配置されるテスト セクションからなる. 整流塔にはアルミのハニカムが内蔵さ れている.テストセクション入口には熱線風速計および熱電 対が配置され，それぞれ主流の風速および温度を計測する。 熱線風速計としてはKANOMAX 社製の MODEL6531を 用いており，応答性は約 1 秒（カタログ值）となっている. 流速計測の不確かさは $\pm 0.13 \mathrm{~m} / \mathrm{s}(\mathrm{RSS})$ である ${ }^{11)}$.テス トセクション部はアクリル製のダクトで構成されており, 断 面積は $60 \times 60 \mathrm{~mm}$ である. 熱交換器下流には上部壁面，下 部壁面からそれぞれ $10 \mathrm{~mm}$ の位置に計二つの熱電対が配置 されている。熱電対の径は $0.25 \mathrm{~mm}$ であり，温度計測の不 確かさは $\pm 1 \mathrm{~K}(\mathrm{RSS})$ である. また熱交換器の前後に全圧 計測用の圧力導管が設置されており，これらの差により全 圧損失を計測する。差圧計は 0.5 inchH $_{2} \mathrm{O}=124.5 \mathrm{~Pa}$ の

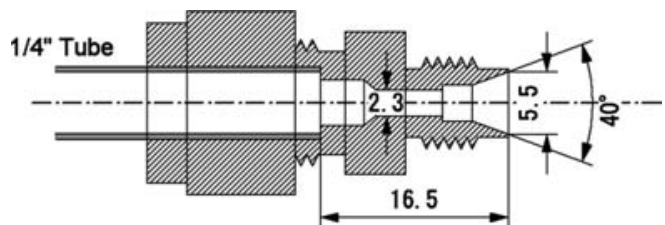

第 3 図 ジェット噴射装置ノズル断面図

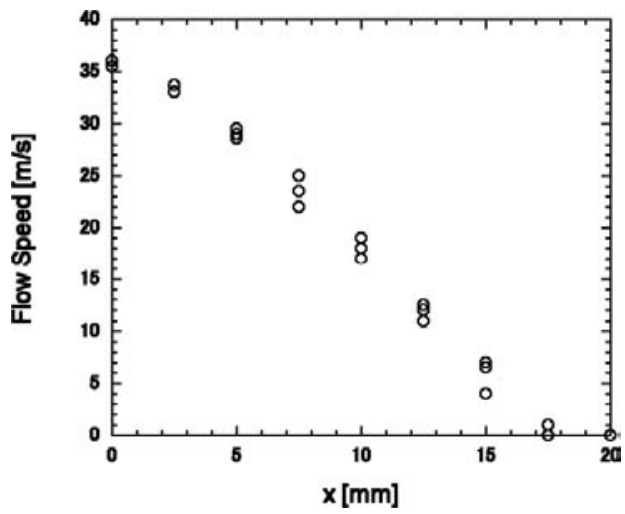

(a) 自由空間中での流速分布

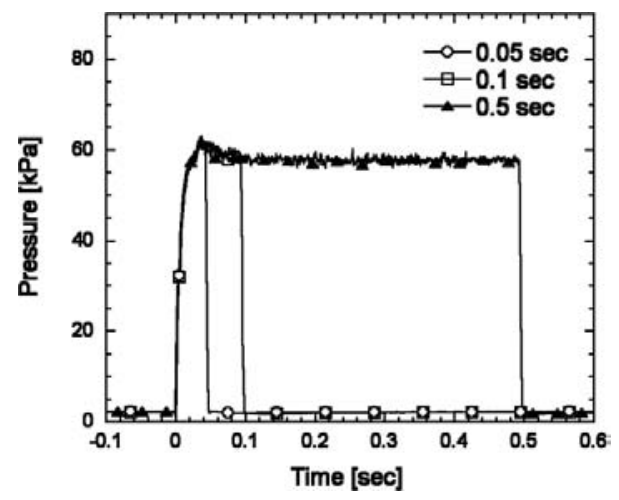

(b) 時間応答特性

第 4 図 ジェットの特性

レンジのもの（Setra 社 Model 204）を使用しており，圧 力計測の不確かさは $\pm 0.5 \mathrm{~Pa}(\mathrm{RSS})$ である.

ジェット噴射装置は電磁弁およびノズルからなる。電磁 弁上流には窒素ガスボンベにより高圧窒素ガスが供給され, 電磁弁の開閉によりジェット噴射を行う。ジェットの元圧 (全圧) は $0.6 \mathrm{MPa}$ に設定した。第 3 図に，テストセクショ ン部分に配置されるジェット噴射装置のノズル断面図を示 す.ノズルには Swagelok 社の 1/4-1/8 inch 異径ユニオン を使用した。このユニオンはラバルノズル形状をしており， スロート部の直径は $2.3 \mathrm{~mm}$, 出口部分の径は $5.5 \mathrm{~mm}$ で ある。ただし電磁弁における流路の最小径が $1.5 \mathrm{~mm}$ とノ ズルスロートより狭い.ノズルは熱交換器上流約 $100 \mathrm{~mm}$ の位置に配置され，第 2 四 (b) のように流路中央から流れ に沿う方向にジェット噴射を行う。ジェットの強さを把握す るため, 直径 $4 \mathrm{~mm}$ のピトー管を用いてジェットの流速計 測を行った結果を第 4 困 (a) に示す。この流速はジェット の出口から $100 \mathrm{~mm}$ 下流で計測されたもので, 図中の $x$ は 


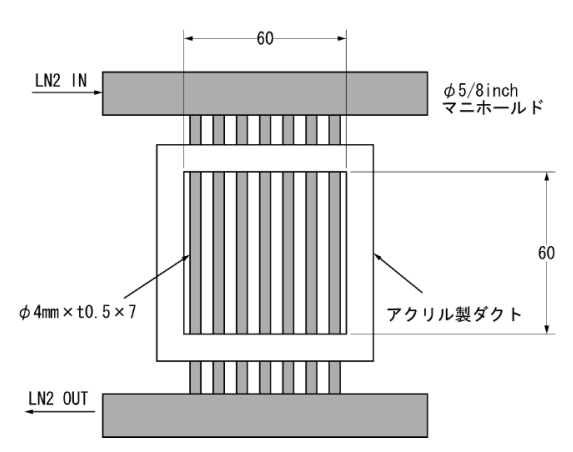

(a) 断面図

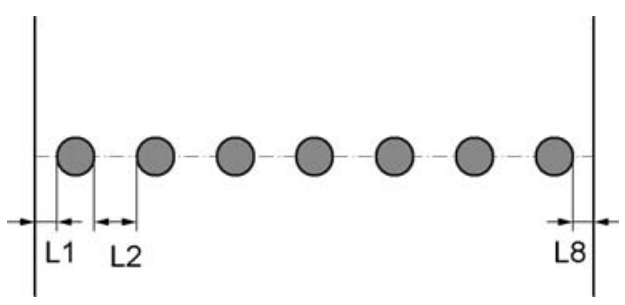

(b) 冷却配管の配置

第 5 図 熱交換器

ジェットの中心軸からの距離を示す．計測の際，ダクトや 熱交換器等は配置していない.ジェットの中心部分の流速 は $35.8 \pm 0.8 \mathrm{~m} / \mathrm{s}$ となった。また本実験ではジェットの噴 射時間を最短で $0.05 \mathrm{~s}$ と短く設定するため, バルブの作動 時間によるジェットの遅れなどが生じるおそれがある。従っ てジェットの非定常的な応答特性を確認する必要があると 考えられ，それを示したのが第 4 図 (b)である. 本図では, 時間応答性のよいフラッシュマウント式の圧力センサを， ズル出口直後に配置し， $0.05 ， 0.1 ， 0.5$ 秒の開指令を与え たときの圧力センサの出力を示している，圧力センサとし ては Kulite 社製の XT-140M-100psi を使用し，その共振 周波数は $400 \mathrm{kHz}$ である. 図より, ジェットを噴射し始め て定常状態の約 $90 \%$ の圧力まで立ち上がるのに約 $0.01 \mathrm{~s}$ を 要していることがわかる。またジェットが定常状態になる には約 $0.1 \mathrm{~s}$ を要するため, ジェット噴射時間が 0.05 秒間 のケースでは過渡的な領域を用いてジェットを噴射してい ることになる。ジェットを停止するときの応答は比較的よ く, $0.01 \mathrm{~s}$ 以下の時間でバルブが閉となる.

第 5 図に，本実験で用いた熱交換器の断面図と冷却配管 の配置図を示す。熱交換器はマニホールドの役割をする外 径 5/8inch の配管と, 7 本の外径 $4 \mathrm{~mm}$ 冷却管からなる. これらはすべて SUS 製である。冷却管の間隔は，左右の壁 面との間隔 $(\mathrm{L} 1$ および $\mathrm{L} 8)$ が $2.3 \mathrm{~mm}$, 冷却管同士の間隔 が $4.6 \mathrm{~mm}$ となっている.

実験条件を第 1 表に示す，表に記されている誤差につい ては恒温恒湿空気供給装置の仕様による。主流流速につい ては, 試験開始前の無冷却状態において熱線風速計を用い て調整しており, 以後実験を開始すると熱交換器に発生す る着霜のため圧力損失が増大し，流速は減少する。流速が $1.0 \mathrm{~m} / \mathrm{s}$ と低いのは恒温恒湿空気供給装置の供給能力限界に

\begin{tabular}{cl}
\multicolumn{1}{c}{ 第 1 表 } & 実験条件 \\
\hline 主流流速 & $1.0 \pm 0.13 \mathrm{~m} / \mathrm{s}$ \\
主流温度 & $23 \pm 1.0^{\circ} \mathrm{C}$ \\
主流湿度 & $59 \pm 3 \%$ \\
\hline
\end{tabular}

よるためであり, 今後装置の改善等により実際のプリクー ラのレベル $(10 \mathrm{~m} / \mathrm{s}$ 程度）にまで増加させる必要がある. また熱交換器の冷媒としては液体窒素を用いており，自 己加圧式のタンクを用いて $0.15 \mathrm{MPa}$ 程度に加圧して供給 している. 加圧することで液体窒素の沸点は若干上昇する. 今回の実験では熱交換器入口, 出口で測定した冷媒温度は $83 \pm 1 \mathrm{~K}$ であり, 入口と出口での温度差は見られなかった. 熱交換器冷却管の厚みは $0.5 \mathrm{~mm}$ と薄く, 熱伝導の式から 計算される冷媒と冷却管表面温度との温度差は $0.5 \mathrm{~K}$ 程度 である。従って熱交換器の冷却管表面温度は $83.5 \pm 1 \mathrm{~K}$ と 推定できる.

以下に今回の実験手順を示す。

（1）熱交換器前後に仕切板を入れる.

（2）仕切板で囲まれた領域に乾燥窒素ガスを流す.

(3) 熱交換器に液体窒素を流し冷却開始.

(4) 約 5 分後, 冷媒入口/出口温度が $83 \mathrm{~K}$ 付近で安定する.

（5）乾燥窒素ガスを止め, 仕切板をはずして実験開始.

なお，すべてのパラメータについてデータの収録は $5 \mathrm{~Hz}$ で行っている。

\section{3. 実 験 結 果}

3.1 ジェット非使用時の熱交換特性 まずジェットを用 いない場合の熱交換器の特性について述べる。第 6 図に, 実験開始時，実験開始後 50 秒，および実験開始後 250 秒に おける熱交換器の配管の映像を示す。試験開始と同時に熱 交換器冷却管に着霜が生じる様子が観察された。着霜は時 間の経過とともに成長し, 最終的に流路が閉塞状態となる. 第 7 図に, ジェットを使用しなかった場合の主流流速 $u_{\infty}$ お よび熱交換器下流温度 $T_{\text {out }}$ の時間変化を示す. 図ではデー 夕の再現性を評価するため, 同条件下で 3 回の実験を行っ た結果を示している。実験開始と同時に熱線風速計による 流速が減少していくことがわかるが，これは着霜により熱 交換器部の圧力損失が増大していることが原因である。主 流流速は時間の経過とともに下降を続け, 開始後約 250 秒 で流路が閉塞し流速が 0 となる。また熱交換器下流温度に 関しては，実験開始後 20 秒付近までの間でいったん上昇し た後下降傾向に転ずる。これは，まず着霜による熱抵抗の ため熱交換性能が低下し下流の温度が上昇するが，時間の 経過とともに流速が減少するため, 空気側の流量が減るこ とが原因であると考えられる。再現性については，0～150 秒までの間では三つのデータが流速について $0.1 \mathrm{~m} / \mathrm{s}$, 熱 交換器下流温度について $1.0 \mathrm{~K}$ 以下の範囲内で一致してお り，良好であると判断する。150 秒以降に関しては，流速， 下流温度ともに乱れが大きくなり，局所的に三つのデータ が一致しない場合が見られる。これは着霜により流速が低 下し，浮力による流れの乱れなどの影響を受けやすくなっ 


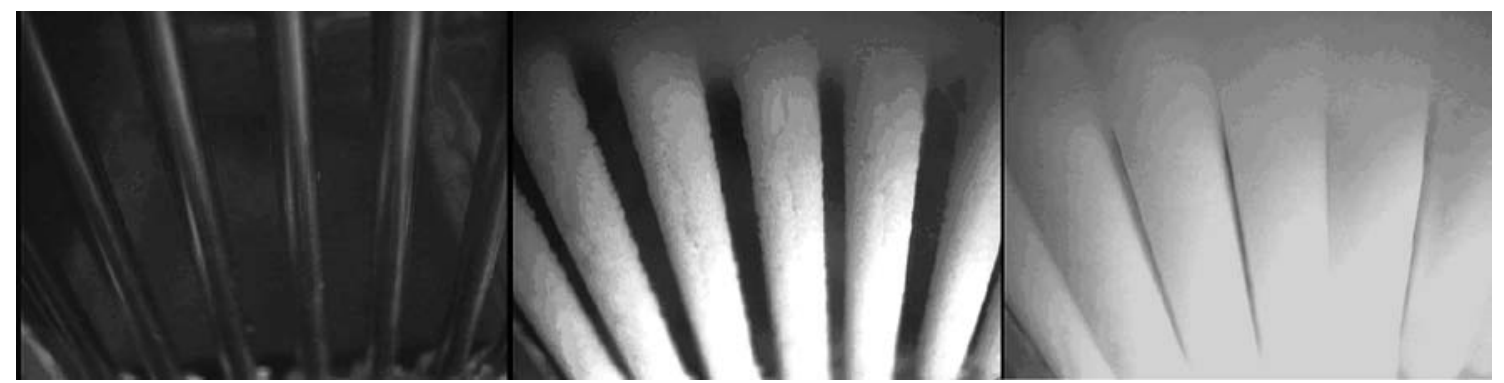

第 6 図 実験開始時 (左), 実験開始後 50 秒（中）および実験開始後 250 秒（右）の熱交換器の映像（映像は熱交換器上方から撮影）

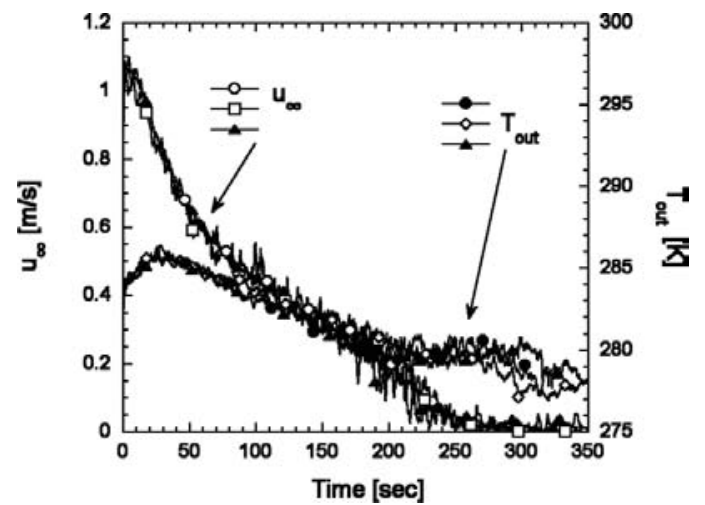

第 7 図 ジェット非使用時の主流流速と熱交換器下流の主流温度

たためと考えられる。

熱交換量に関しては以下の式により算出する.

$$
Q=\rho_{\infty} u_{\infty} A c_{\mathrm{p}}\left(T_{\mathrm{in}}-T_{\text {out }}\right)
$$

ここで $Q$ は熱交換量, $\rho_{\infty}$ は主流空気の密度, $A$ は流路断 面積， $c_{\mathrm{p}}$ は定圧比熱， $T_{\mathrm{in}}$ は熱交換器上流で計測した空気 温度である． $T_{\text {out }}$ に関しては空間的にばらつきを生じるお それがあるため，まずは予備実験として，第 8 図に示すよ うな温度レークを使用して空間的なばらつきを調べた。こ の温度レークには, シース径 $0.25 \mathrm{~mm}$ の熱電対が流路断面 の中心および上下左右の計 5 カ所に配置してある。予備実 験の結果，第 8 図 (b) に示すと打り温度の空間的なばらつ きは上下の差を除いて無視できる範囲であることがわかっ た. 第 9 図に, ジェット非使用時の熱交換量を示す. 本図 には, Case A として， $T_{\text {out }}$ を決定するのに上下 2 本の熱 電対のみを用いた場合と, Case B としてレークの熱電対 5 本すべてを平均化して求めた場合の $Q$ のグラフを示して あるが，流速がきわめて遅くなる 200 秒付近に至るまで両 者はよく一致していることが確認できる。従って以後の実 験では, $T_{\text {out }}$ を上下 2 本の熱電対の平均として求めた温度 を使用することとした，また第 9 図に㧍いて，圧力損失係 数 $\Delta c_{\mathrm{p}}$ に関しては以下の式を用いて算出している.

$$
\Delta c_{\mathrm{p}}=\frac{\left(p_{0 \text { in }}-p_{0 \text { out }}\right)}{1 / 2 \rho_{\infty} u_{\infty}^{2}}
$$

(2) 式において， $p_{0 \text { in }}, p_{0 \text { out }}$ はそれぞれ熱交換器上流，下 流の全圧， $\rho_{\infty}$ は入口主流空気密度である. 時間の経過と
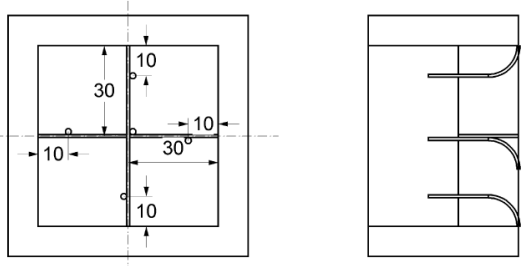

(a) 温度レーク外観図と熱電対の配置. 単位 $\mathrm{mm}$
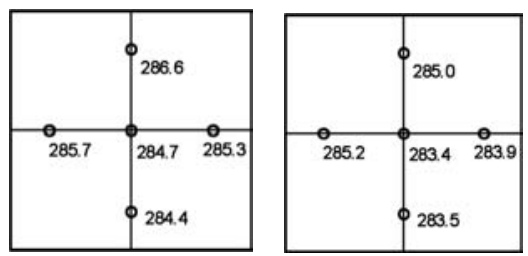

(b) 熱交換器下流温度の空間的なばらつき. 左は実験開始後 50 秒, 右は 100 秒の温度分布

第 8 図 温度レークによる熱交換器下流温度の空間的分布計測

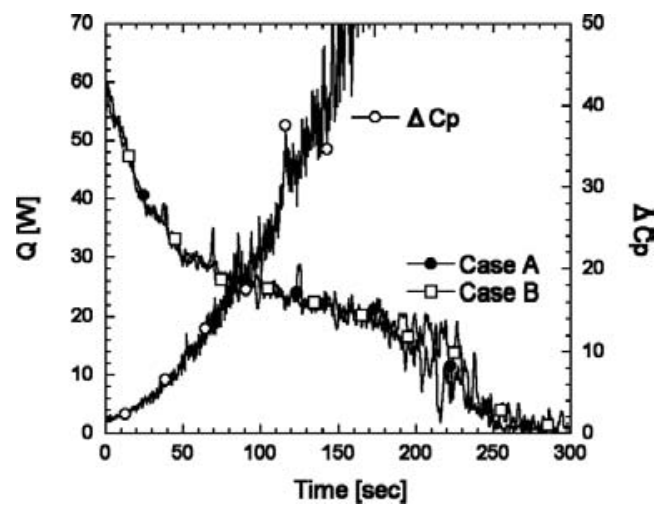

第 9 図 ジェット非使用時の熱交換量と圧力損失

ともに熱交換量に関しては減少し, 圧力損失に関しては増 大寸る傾向が見られるが，これらはともに着霜によるもの である。

3.2 ジェット使用時の熱交換特性 第 10 図に, 試験開 始後 50 秒で噴射時間 0.1 秒のジェットを噴射した場合の, 噴射前後における冷却配管の映像を示す。ジェットの噴射に より霜が吹き飛ぶ様子が観測でき，冷却管同士の間隔が第 6 図左の実験開始時とほほ同等にまで広がっている様子がわ かる. 第 10 図右の写真にあるように, 霜層は完全には除去 


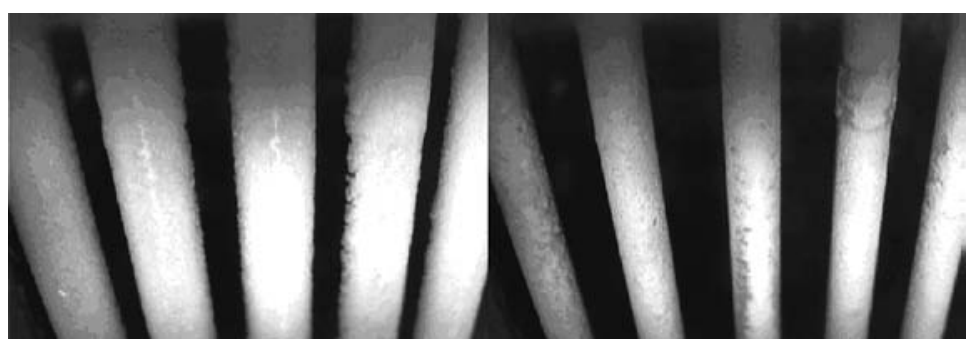

第10図 ジェット噴射による霜の吹き飛びの様子 左：ジェット噴射直前，右：ジェット噴射直後.

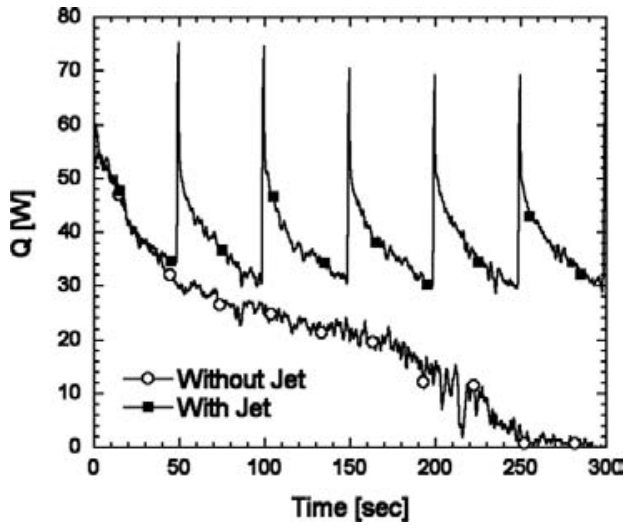

第11図 ジェットを使用した場合の熱交換量

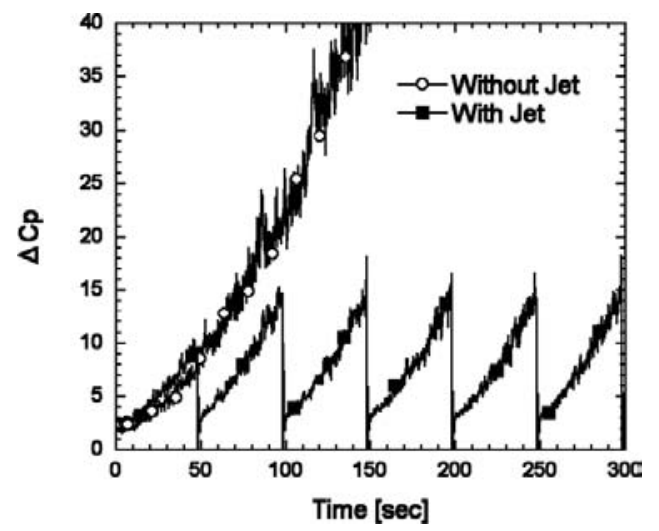

第 12 図 ジェットを使用した場合の圧力損失

されず，冷却管の表面には薄い層が残る。しかし残留する 層は十分に薄く, 熱交換量, 圧力損失ともに大幅に改善さ れる、第 11 困に，上記ジェット噴射時の熱交換量の変化を， ジェットを使用していない場合と合わせて示す。ジェット噴 射と同時に霜が吹き飛び, それに伴い風速計の指示值が増 加し, また熱交換器下流の空気温度も下降するため, 結果 として熱交換量が回復する。第 12 図には同様に圧力損失 係数の時間变化を示す. 圧力損失係数に関しても, 50 秒に おけるジェット噴射により急激に回復している様子がわか る.これらの結果により, 今回準備したジェットには十分 な除霜効果があることが確認された。ただし第 12 図によ ると, 実験開始後 50 秒におけるジェット噴射直前では $\Delta c_{\mathrm{p}}$ は約 10 であるが，2 回目の 100 秒におけるジェット噴射の

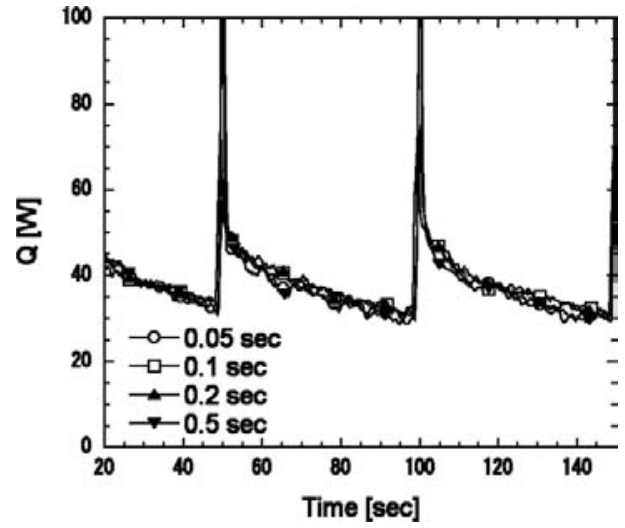

第 13 図 ジェット噴射時間を変化させたときの熱交換量への影響

第 2 表 各噴射時間における 0 299 秒の熱交換量の 時間平均值

\begin{tabular}{cc}
\hline ジェット噴射時間 $[\mathrm{s}]$ & 平均熱交換量 $[\mathrm{W}]$ \\
\hline 0.5 & 39.1 \\
0.2 & 39.8 \\
0.1 & 37.9 \\
0.05 & 38.2 \\
\hline
\end{tabular}

直前では $\Delta c_{\mathrm{p}}$ は約 15 である。これは映像でもわかるとお り，ジェット噴射により霜層が完全に除去される訳ではな く，表面に薄い層が残ることが原因であると考えられる。

第 13 図はジェットの噴射時間を変化させたときの熱交換 量への影響を示したグラフである．高圧ガス源の消費量削 減の意味から, ジェットの噴射時間は極力短い方が望まし い. 第 13 図では試験開始から 50 秒および 100 秒後に, そ れぞれ $0.5,0.2,0.1,0.05$ 秒間ジェットを噴射した場合の 熱交換量の変化を比較している. ジェットの噴射時間が長い 場合, 噴射直後の熱交換量は通風開始直後の值 (約 $60 \mathrm{~W}$ ) を上回るが，これはジェットの長時間噴射により一時的に 大量の空気が引き込まれることが原因と考えられる。この 通風開始直後の值を上回る熱交換量の増加は長続きせず, 数秒後には短秒時の噴射と同等の值にまで下がってしまう. 従って時間平均した熱交換量の増加には大きく寄与しない. 第 2 表に，0〜299 秒の熱交換量の時間平均值を示す. 参考 として，0.1 秒間ジェットを吹いた場合について，3 回の実

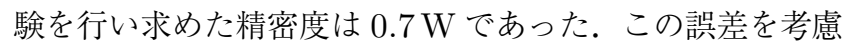
すると, ジェット噴射時間を 0.05 秒程度に短くしても, 平 均熱交換量はほとんど変化しないことがわかる。 


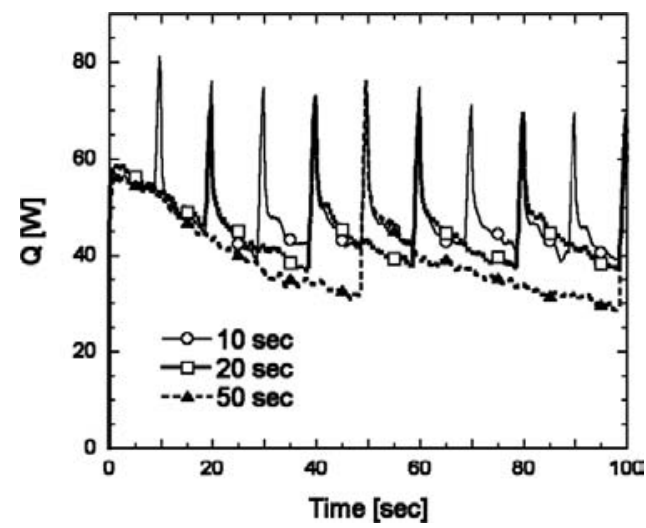

第 14 図＼cjkstart噴射間隔の違いによる熱交換量の変化

第 3 表 各噴射間隔における 0 299 秒の熱交換量の 時間平均值

\begin{tabular}{cc}
\hline ジェット噴射間隔 $[\mathrm{s}]$ & 平均熱交換量 [W] \\
\hline 10 & 45.2 \\
20 & 42.6 \\
50 & 37.9 \\
\hline
\end{tabular}

第 14 図に，噴射間隔を 10 秒，20 秒，50 秒と変化させ た場合の熱交換量を示す。1 回の噴射における噴射時間は いずれのケースでも 0.1 秒である。噴射間隔を短くするこ とで熱交換量の時間平均值はより大きくなる。第 3 表にそ れぞれの噴射間隔における 0 299 秒の熱交換量の時間平 均值を示す。それぞれのケースにおいて，1回の噴射時間は 同じく 0.1 秒である．噴射間隔を 10 秒にすると，噴射間隔 が 50 秒の場合と比較して熱交換量の時間平均值は $20 \%$ ほ ど増加することがわかった。ただし第 14 図を見ると，噴射 間隔を 10 秒とした場合において，最初のジェット噴射直後 の熱交換量は，噴射間隔が 20 秒および 50 秒の熱交換量と 違いがない。これは霜層がある程度蓄積しないとジェット 除霜の効果がないことを意味している。従って噴射間隔を 短くすることによる熱交換量の増加には限度があると考え られる。また，噴射間隔を短くすればするほど使用するガ スの量が多くなり，ガスタービンに搭載した場合その分だ け性能悪化を招くことになる。実用化の際にはこれらのこ とを考慮して噴射間隔を決定する必要がある。

以下に，今回の実験で除霜のために使用したジェットの 流量と, 主流を流れる空気の流量の比を求めてみる。除 霜のためのジェットの質量流量 $\dot{m}_{\mathrm{j}}$ は, もっとも流路面 積が小さい電磁弁においてチョークしていると考えると, $\dot{m}_{\mathrm{j}}=2.50 \times 10^{-3} \mathrm{~kg} / \mathrm{s}$ である. 一方, 主流の質量流量は $\dot{m}=4.34 \times 10^{-3} \mathrm{~kg} / \mathrm{s}$ である。ただし第 14 図における ジェット流量のうち最大の場合でも, ジェットは 10 秒ごと に 0.1 秒間しか噴射しない。このときジェットと主流の質 量流量比 $\phi$ は

$$
\phi=\frac{\dot{m}_{\mathrm{j}}}{\dot{m}} \times \frac{0.1}{10}=0.58 \%
$$

となる。従って，今回のケースではジェット除霜に必要な 流量はタービン翼冷却用のバイパス空気等と比較しても十

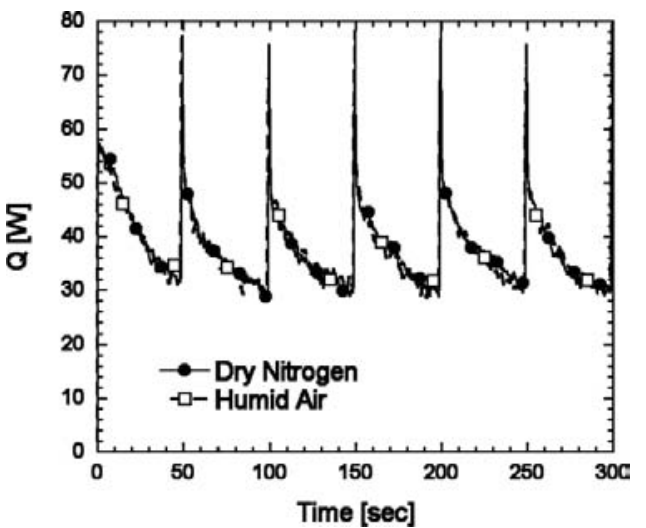

第 15 図 湿り空気ジェットによる除霜の効果

分少ない.

第 15 図には，ジェットの供給源を乾燥窒素ボンベからド ライヤーを装備しないコンプレッサに変え, 第 11 図と同様 に 50 秒間隔，0.1 秒間のジェットを噴射し除霜を行った際 の熱交換量を示す。参考として，実験実施時の実験室内温 度，湿度は $19.6^{\circ} \mathrm{C} ， 41 \%$ であった。今回提案する除霜方法 は，稲葉ら ${ }^{12)}$ の研究のようにジェットにより霜を昇華させ ることを意図したものではなく，衝突による力で吹き飛ば すことを意図したものである。従ってジェット気体の湿度 には影響されず，湿り空気の場合でも乾燥窒素の場合と同 一の除霜効果が得られた。このことは実用化に際し水蒸気 を含む圧縮機下流の空気をジェットの供給源としても問題 がないことを意味する。

\section{4.おわりに}

予冷ターボエンジンにおけるプリクーラの除霜を目的と して，高速ジェットを極低温熱交換器冷却管に衝突させる ことで除霜を行う手法の成立性を実験により検証した。主 流流速 $1.0 \mathrm{~m} / \mathrm{s}$, 温度 $23^{\circ} \mathrm{C}$, 湿度 $59 \%$, 配管径 $4 \mathrm{~mm}$ の単 列熱交換器では, 0.1 秒間程度のごく少流量のジェット噴射 でも十分な熱交換量/圧力損失の改善が見られることが明ら かになった.

今回の実験でジェット噴射による除霜の有効性が確認され たのは，冷媒として液体窒素を用い冷却面の温度が約 $83 \mathrm{~K}$

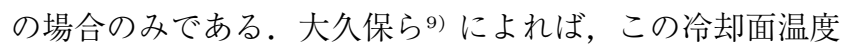
において発生する霜層は第 IV 領域に分類され，他の冷却 面温度において発生する霜よりもろい. 従ってジェット除霜 にとってはもっとも有利な条件である。しかし実際のプリ クーラでは，冷却面温度は冷媒入口付近における極低温か ら冷媒出口付近における $0^{\circ} \mathrm{C}$ 近辺まで，あらゆる冷却面温 度が存在する。今後は他の冷却面温度についても本除霜方 法の有効性を確認する必要がある。また，今回の実験では 単列の熱交換器についてジェットによる除霜を行ったが，実 際のプリクーラにおいては多列管群が用いられている。管 群が多列になった場合，ジェットが後流側の管群にまで到 達せず，除霜の効果が薄れる可能性がある。この場合, 上 流からのジェット噴射に加え，側面からの噴射も追加する 
などの工夫が必要となるかもしれない。しかし, 熱交換器 の泠却面が極低温の場合, 着霜は最前列の管群の上流側に 集中するという特徵がある。このことを考慮すると上流の みからのジェット噴射でも十分な効果が得られる可能性も あり, 今後の研究での解明が待たれる。

本研究の実験を実施するにあたり，宇宙航空研究開発機 構宇宙科学研究本部の澤井秀次郎准教授に多大な協力を頂 いた．また，本研究の一部は科学研究費補助金（基盤研究 C19560793）の補助を受けて実施したものである。ここに 記して謝意を表する。

\section{参 考 文 献}

1) Sato, T., Taguchi, H., Kobayashi, H., Kojima, T., Okai, K., Fujita, K., Masaki, D., Hongoh, M. and Ohta, T.: Development Study of Precooled-Cycle Hypersonic Turbojet Engine for Flight Demonstration, Acta Astronautica, 61 (2007), pp. $367-375$.

2) 久角喜徳：LNG 冷熱利用の新展開, 日本機械学会論文集 B 編, 73 (2007), pp. 1155-1159.
3) 佐藤哲也, 棚次亘弘, 原田賢哉, 小林弘明, 富家純一郎: 極超音 速空気吸い込み式エンジン用予冷却器（プリクーラ）の開発研究, 日本航空宇宙学会論文集, 50 (2002), pp. 196-203.

4) 福迫尚一郎, 稲葉英男: 低温環境下の伝熱現象とその応用, 養賢 堂, 東京, 1996, pp. 240-278.

5）日本冷凍協会冷凍空調便覧編集部会：冷凍空調便覧，日本冷凍協 会, 東京, 1981, pp. 355-359.

6) Harada, K., Tanatsugu, N. and Sato, T.: Development Study of a Precooler for the Air-Turboramjet Expander-Cycle Engine, J. Propul. Power, 17 (2001), pp. 1233-1238.

7) 木村竜也，佐藤哲也：凝縮性物質を用いた空気予冷却器（プリ クーラ）の着霜軽減に関する研究, 日本航空宇宙学会論文集, 51 (2003), pp. 597-605.

8) 吹場活佳, 佐藤哲也, 大久保英敏: 予冷却ガスタービンシステム の除霜方法，及び除霜装置，国内特許，特願 2007-45576, 2007.

9) 大久保英敏, 田島 収: 着霜現象に及ぼす冷却面表面温度の影響, 日本冷凍協会論文集, 12 (1995), pp. 285-294.

10) 原田賢哉：極低温冷媒を用いた空気熱交換器の着霜に関する研究, 東京大学博士論文, 1999, pp. 78-139.

11) アメリカ機械学会編, 日本機械学会訳：計測の不確かさ, 日本機 械学会, 東京, 1987, pp. 3-53.

12) 稲葉英男, 堀部明彦, 川上理亮: 着霜 2 鉛管の昇華による除霜挙 動，日本機械学会論文集 B 編， 66 (2000), pp. 2964-2971. 